\title{
Comparison of endometrial regenerative cells and bone marrow stromal cells
}

\author{
Huan Wang ${ }^{1}$, Ping Jin ${ }^{1}$, Marianna Sabatino ${ }^{1}$, Jiaqiang Ren ${ }^{1}$, Sara Civini ${ }^{1}$, Vladimir Bogin² ${ }^{2}$ Thomas E Ichim ${ }^{2}$ and \\ David F Stroncek ${ }^{1,3^{*}}$
}

\begin{abstract}
Background: Endometrial regenerative cells (ERC) and bone marrow stromal cells (BMSC) are being used in clinical trials. While they have been reported to have similar characteristics, they have not been directly compared.

Methods: We compared micro RNA (miRNA) and gene expression profiles, soluble cytokine and growth factor levels and ability to inhibit ongoing mixed leukocyte reaction (MLR) of ERC and BMSC each derived from 6 healthy subjects.

Results: ERC and BMSC miRNA and gene expression profiles were similar, but not identical; more differences were noted in the expression of genes than in miRNAs. Genes overexpressed in ERCs were more likely to be in immune and inflammation pathways and those overexpressed in BMSCs were more likely to be in stem cell and cancer signaling pathways. In addition, the levels of IL-8 and ICAM-1 were greater in ERC supernatants while the levels of HGF, VEGF, IL-6, CXCL12, TGFB1 and TGFB2 were greater in BMSC supernatants. Additionally, ERC demonstrated greater inhibition of the proliferation of mixed leukocyte cultures.

Conclusions: These results suggest that the in vivo effects of ERC and BMSC may differ. Multiple properties of stromal cells are responsible for their in vivo effectiveness and ERC may be more effective for some of the clinical applications and BMSC for others. Studies in animal models or clinical trials will be required to more fully characterize the differences between ERC and BMSC.
\end{abstract}

Keywords: Endometrial regenerative cells, Bone marrow stromal cells, Mesenchymal stromal cells, Mesenchymal stem cells, Regenerative medicine

\section{Background}

Mesenchymal stem cells (MSC) have been the subject of numerous studies for their ability to differentiate into various specialized cells and their great therapeutic potential, particularly in tissue regeneration. These cells have been isolated from many different tissues. One of the most commonly investigated MSC are those derived from bone marrow, which are known as bone marrow stromal cells (BMSC). These are fibroblast-like, plastic adherent cells from the bone marrow [1] that express CD73, CD90 and CD105 [2,3]. These multipotent cells have the ability to differentiate into

\footnotetext{
* Correspondence: dstroncek@cc.nih.gov

'Department of Transfusion Medicine, Clinical Center, National Institutes of Health, Bethesda, MD, USA

${ }^{3}$ Department of Transfusion Medicine, Cell Processing Section, 10 Center Drive-MSC-1288, Building 10, Room 3C720, Bethesda, MD 20892-1288, USA Full list of author information is available at the end of the article
}

osteoblast, chondrocyte, and adipocyte colonies $[4,5]$ and have been shown to be capable of bone regeneration [6,7], effective in treating acute graft-versus-host-disease (GVHD) [8-10] and have been investigated to treat other diseases such as cirrhosis [11], ischemic heart disease [12], Crohn's Disease [13] and autoimmune disorders.

Meng and collaborators [14] have isolated a type of stromal cell from menstrual blood, Endometrial Regenerative Cells (ERC), which also have promising clinical potential. These cells are not specifically classified as MSC, though they do express most MSC markers such as CD9, CD29, CD41a, CD44, CD59, CD73, CD90, and CD105. ERC are distinct from previously characterized endometrial stromal cells, or endometrial mesenchymal stem cells, in that they do not express the BMSC marker STRO-1 $[14,15]$. They can differentiate into tissue types beyond bone, fat, and cartilage and therefore may be 
pluripotent to some degree $[14,15]$. Studies in animal models also suggest that ERC can be used to treat critical limb ischemia via stimulation of angiogenesis [15], inhibit glioma growth and reduce tumor neovascularization and possess immunosuppressive properties $[15,16]$. Furthermore, unlike embryonic stem cells, ERC do not appear to pose the risk of teratoma development in vivo [14], and they are easily collected and expanded. A phase I clinical study performed on four multiple sclerosis patients showed that ERC could be used allogenically and safely, and the treatment seemed to have prevented disease progression [17]. In addition, the FDA has granted the approval for ERC to be used in additional human clinical trials. Although early evidence shows a promising future for the allogeneic use of ERC in human patients, it is nevertheless necessary to confirm and expand our current understanding.

We compared ERC and BMSC by examining their morphology, cytokine production, inhibition of mixed leukocyte reactions (MLRs), micro RNA (miRNA) expression and global gene expression. We hypothesized that the two types of cells would exhibit different properties which could result in distinct functional and clinical properties.

\section{Materials and methods \\ Study design}

Six different ERC samples and six different BMSC samples from individual donors were chosen and culture for 67 days. Since the media normally used to support the growth of ERC and BMSC were different, we grew the ERC in both media to determine if any differences between ERC and BMSC were due to culture medium type. We compared ERC and BMSC by analyzing the global gene expression and miRNA profiling, cytokine production, morphology and inhibition of MLR. Hematopoietic stem cell (HSC), embryonic stem cell (ESC) and fibroblast lines were utilized as controls in miRNA and global gene expression comparisons. This study was approved by the NHLBI Institutional Review Board.

\section{Cell lines}

The ERC were provided by MediStem (MediStem Inc., San Diego, CA, USA), BMSC were obtained from marrow aspirates of healthy subjects (Cell Processing Section, Department of Transfusion Medicine, Clinical Center, NIH Bethesda, MD, USA), the fibroblasts were CRL2429, CRL2352 (ATCC, Manassas, VA, USA) and NuFF1(Global Stem Inc, Rockville, MD, USA), the ESC were H9 (WiCell Research Institute, Madison, WI, USA), I6 (Technion-Israel Institute of Technology, Haifa, Israel) and $\mathrm{BG} 01 \mathrm{v}$ (ATCC), the HSC were $\mathrm{CD}^{+}{ }^{+}$cells were isolated with monoclonal antibodies and paramagnetic beads from G-
CSF-mobilized peripheral blood stem cell concentrates (Cell Processing Section, NIH).

\section{Culture of ERC}

Six frozen human ERC lines were thawed from liquid nitrogen, washed, and manually counted. Passage 1 cells were first expanded to Passage 2 in Modified Eagle Medium with Nutrient Mixture F-12 with $10 \%$ fetal bovine serum and $10 \mu \mathrm{g}$ gentamicin (ERC medium). Passage 2 cells were then plated on two $75 \mathrm{~cm}^{2}$ culture flasks at a density of approximately $3 \times 10^{3}$ cells $/ \mathrm{cm}^{2}$ in two types of media: ERC Medium and alpha Minimum Essential Medium with $20 \%$ fetal bovine serum and $10 \mu \mathrm{g}$ gentamicin (BMSC medium). Cells were observed for adherence after $24 \mathrm{~h}$ and culture medium was changed after 3 days. Once cells reached $>80 \%$ confluence (6-7 days), they were harvested for analysis. Two to three million cells were lysed in $1 \mathrm{ml}$ Trizol and $3 \mathrm{ml}$ of supernatant was collected for proteomic analysis. Cells cultured in ERC media were designated ERC-E and in BMSC media ERC-B.

\section{Culture of BMSC}

Frozen human BMSC isolated from bone marrow aspirates were thawed from liquid nitrogen, washed, and manually counted. Passage 2 BMSC were plated on $75 \mathrm{~cm}^{2}$ flasks at a density of $3 \times 10^{3}$ cells $/ \mathrm{cm}^{2}$ in BMSC medium and observed for adherence after $24 \mathrm{~h}$. Culture medium was changed after 3 days. Passage 3 cells were harvested at $>80 \%$ confluence after 6-7 days for further analysis. Two to three million cells were lysed in $1 \mathrm{ml}$ Trizol and $3 \mathrm{ml}$ of supernatant were collected for proteomic analysis.

\section{Cell imaging of embryonic stem cell marker analysis}

BMSC and ERC at passage 2 were thawed and cultured in BMSC medium at a density of $1 \times 10^{5}$ cells per well in flat bottom six-well plates. Cell medium was changed after 3 days and light microscopy images were taken for both cell types. Cell medium was aspirated after 6 days of culture; cells were washed with 1X PBS and fixed with $4 \%$ paraformaldehyde. Cells were permeabilized with $1 \%$ saponin in PBS and were stained for the following embryonic stem cell markers: Oct-4, Nanog, SSEA-4, SSEA-1, Klf-4, and TRA-1-81 at room temperature overnight. Cells were rinsed with $1 \%$ saponin and incubated with anti-tubulin for 1 hour, washed with $1 \%$ saponin, and rinsed with $1 \mathrm{X}$ PBS before observation by immunofluorescence microscopy (Zeiss Axio Observer Inverted Microscope Carl Ziess, Gottingen, Germany).

\section{Measuring cytokine and growth factor levels with proteome profiler antibody arrays}

Supernatants from 3 ERC samples (ERC-B) and 3 BMSC samples cultured in BMSC medium and 3 BMSC samples 
cultured in the same medium were analyzed for soluble proteins and cytokines related to immunomodulation using the Proteome Profiler Human Cytokine Array KitPanel A (R\&D Systems, Minneapolis, MN, USA), which detects most common immunomodulatory cytokines. Each supernatant sample was incubated with a cytokine panel membrane according to manufacturer's protocol with modifications. Incubation times were doubled to optimize signal detection. The membranes were scanned (ChemiDocsTM XRS + plus ImageLab) and analyzed with Bio-Rad Image Lab software (Bio-Rad Laboratories, Hercules, CA, USA). Semi-quantitative analysis was performed by measuring the average pixel intensity of each array, normalizing the values to the intensity of the positive control, and subtracting the background. The sample intensity to control ratio was the average of the 3 ERC samples and 3 BMSC samples, respectively.

\section{Supernatant cytokine and growth factor analysis using searchlight protein array}

Three ERC-B and 3 BMSC supernatant samples were evaluated for cytokine concentrations using SearchLight Protein Array Analysis (Aushon Biosystems, Billerica, MA, USA). The cytokines and growth factors measured were: human fibroblast growth factor beta (FGFb), hepatocyte growth factor (HGF), platelet-derived growth factor-BB (PDGFBB), Vascular endothelial growth factor (VEGF), Interleukin 10 (IL-10), Interleukin 6 (IL-6), chemokine (C-X-C) ligand 12 (CXCL12), Transforming growth factor beta 1 (TGFB1), and Transforming growth factor beta 2 (TGFB2).

\section{Mixed leukocyte reaction inhibition}

The immunosuppressive properties of BMSC and ERC were compared using an MLR assay (SAIC-Frederic, Frederic, MD). Ficoll-separated peripheral blood mononuclear cells (PBMC) were plated in 96-well plates at $1 \times 10^{5}$ responders per well. Responders were co-cultured with 2500 cGy irradiated stimulator PBMC at a concentration of $1 \times 10^{5}$ cells/well. BMSC and ERC were added at the following concentrations, $10^{4}$ and $10^{5}$ cells/well. Culture plates were incubated for 6 days in a humidified $5 \% \mathrm{CO}_{2}$ incubator at $37^{\circ} \mathrm{C}$. On the day of harvest, $0.5 \mu \mathrm{Ci}$ of $3 \mathrm{H}$-thymidine ( $3 \mathrm{H}$-TdR) was added to each well for 4 hours with lymphocyte proliferation measured using a liquid scintillation counter. The effect of BMSC on MLR was calculated as the percentage of the suppression compared with the proliferative response of the positive control without BMSC, where the positive control was set to $0 \%$ suppression. The experiments were performed three times for each variable described.

\section{Gene expression analysis}

Total RNA from ERC, BMSC, fibroblast, ESC, and HSC samples were extracted using miRNA Easy Kit (Qiagen,
Valencia, CA, USA). RNA concentration was measured using ND-8000 spectrophotometer (Nano Drop Technologies, Wilmington, DE, USA).

Microarray expression experiments were performed on $4 \times 44 \mathrm{~K}$ Whole Human Genome Microarray (Agilent technologies, Santa Clara, CA, USA), according to the manufacturer's instructions. The Universal Human Reference RNA (Stratagene, Santa Clara, CA, USA) was co-hybridized with each sample. Images of the arrays were acquired using a microarray scanner G2505B (Agilent technologies) and image analysis was performed using feature extraction software version 9.5 (Agilent Technologies). The Agilent GE2-v5_95 protocol was applied using default settings. The resulting data files were either uploaded to the mAdb database (http://nciarray.nci.nih.gov/) and further analyzed using BRBArrayTools [18] developed by the Biometric Research Branch, National Cancer Institute (http://linus. nci.nih.gov/BRB-ArrayTools.html) or imported and analyzed using Partek Genomics Suite 6.5 (Partek, Inc, St Louis, MO). Hierarchical cluster analysis and TreeView software were used to visualize the data, and Ingenuity Pathway Analysis (IPA, Ingenuity Systems, Redwood City, CA, USA) was used to perform gene pathway analysis.

\section{Quantitative reverse transcription real time PCR (qRT-PCR)} Quantitative RT-PCR was performed to confirm the expression of selected genes differentially expressed between ERC and BMSC as determined by microarray studies. One $\mu \mathrm{g}$ of total RNA from 6 BMSC, 6 ERC-B, 6 ERC-E, 3 Fibroblast, 2 ESC, and 2 HSC samples were reverse transcripted (RT) with random hexamer primer and the RT product was further diluted for TaqMan Gene Expression Assays (Applied Biosystems, Carlsbad, CA, USA) using standard settings. The genes selected were tumor necrosis factor superfamily 4 (TNFSF-4,), interleukin 8 (IL-8), intercellular adhesion molecule 1 (ICAM-1), vascular cell adhesion molecule 1 (VCAM-1), integrin alpha 10 (ITGA-10), prostaglandin-endoperoxide synthase 2 (PTGS2), and matrix metallopeptidase 3 (MMP3). Gene expressions were quantified with TaqMan Gene Expression Assay of each above listed gene (Assay IDs: Hs00182411; Hs99999034_m1; Hs00164932_m1; Hs01003372_m1; Hs00174623_m1; Hs00153133_m1; Hs00968305 respectively, Applied BioSystems, Life Technologies, Santa Clara, CA, USA). All reactions were run in duplicate. Real-time PCR was performed using ABI 7900 HT Real-time PCR system. The data was acquired using ABI SDS v2.3 software determining the threshold cycle $(\mathrm{Ct})$ by normalizing to the endogenous control $18 \mathrm{~s}$ RNA (Hs99999901_s1, Applied Biosystems). The fold change of each gene against the calibrator was calculated using the equation $2^{-\Delta \Delta \mathrm{Ct}}$. 


\section{miRNA expression analysis}

MiRNA profiling was performed on Agilent's 8x15K human miRNA microarray chips. Total RNA from 4 ERC-B, 3 BMSC, 3 fibroblast, 3 ESC, and 3 HSC samples were labeled and hybridized according to manufacturer's instruction. Slides were scanned using Agilent Microarray Scanner Version C, and data were extracted using Feature Extraction software version 11.0 (Agilent Technology). Data analysis was performed by using Partek Genomics Suite 6.5 (Partek, Inc, MO).

\section{Results}

Cell morphology, growth and stem cell marker expression ERC were cultured in both BMSC medium (ERC-B) and a modified ERC medium based on the formulation used by Medistem, Inc (ERC-E). We hypothesized that the growth rate and morphology of ERC would not be affected by the difference in tissue culture medium. Population doubling time (PDT) was calculated revealing that ERC-B had a slightly shorter average PDT when compared with ERC-E (Table 1); however, no morphological differences were observed for ERC cultured in different media (Figure 1A, B). When compared with BMSC, ERC had a longer PDT (Table 1), larger cytoplasmic area and were less spindly (Figure $1 \mathrm{~A}-\mathrm{C}$ ). Immunofluorescence imaging revealed that both ERC (Figure 2A,B) and BMSC (Figure 2C,D) were positive for Oct-4 while both types of cells were found to be negative for SSEA1, SSEA4, Nanog, TRA-181, and Klf-4 (data not shown).

\section{Soluble protein production}

Soluble cytokines and growth factors expressed by ERC were examined and compared to those expressed by BMSC. ERC supernatant was taken from ERC-B to minimize the differences due to culture medium. ERC and BMSC produced many of the same cytokines albeit at varying levels (Table 2). Among the proteins with high signal intensities IL-8 and soluble ICAM-1 (CD54) were notably higher in ERC supernatant than that of BMSC (Table 2). We also measured the concentration of proteins which were reported to provide some of the beneficial effects of BMSCs [19] using a multiplex ELISA platform (Searchlight) and found that BMSC supernatants had higher concentrations of HGF, VEGF, IL-6, CXCL12, TGFB1 and TGFB2 than ERC supernatants

Table 1 Population doubling time of ERC and BMSC

\begin{tabular}{lccc}
\hline Cell Type & Culture Media & Number & PDT (hours) \\
\hline ERC & BMSC Medium & 7 & 42.8 \\
\hline ERC & ERC Medium & 7 & 47.6 \\
\hline BMSC & BMSC Medium & 4 & 40.3 \\
\hline PDT $=$ population doubling time. & &
\end{tabular}

(Table 3). bFGF, PDGFBB and IL-10 levels were too low to be detected in either group.

\section{Mixed leukocyte reaction inhibition}

The immunosuppressive capabilities of both ERC and BMSC were investigated by MLR inhibition. When responder T cells were stimulated in the presence of ERC$\mathrm{B}$ and BMSC at a concentration of 10,000 cells per well, the BMSC were generally more immunosuppressive. However, a two-sample equal variable $T$-test revealed that this difference was not statistically significant (Figure 3). When responder $\mathrm{T}$ cells were stimulated in the presence of ERC-B and BMSC at a concentration of 100,000 cells per well, ERC-B were significantly more immunosuppressive $(P<0.0002)$.

\section{Gene expression, class comparison and pathway analysis}

Global gene expression analysis was used to profile the ERC-E, ERC-B, BMSC, HSC, fibroblasts, and ESC. Principal Component Analysis (PCA) performed on the entire dataset of 34,127 genes revealed that the samples formed four distinct clusters (Figure 4A). The HSC were in one cluster and ESC in a second; both clusters were located far from each other and from the rest of the samples. Another cluster was made up of fibroblasts which was closer to the fourth cluster made up of the ERC-E, ERC-B and BMSC. This suggested that ERC and BMSC were similar to each other and they were more similar to fibroblasts than to ESC or HSC from a global perspective. There were, however, some differences between ERC and BMSC. A PCA analysis of fibroblast, ERC-E, ERC-B, and BMSC samples with HSC and ESC removed revealed that the fibroblasts, ERC and BMSC formed three distinct groups, but the analysis did not separate ERC-E and ERC-B (Figure 4B). Unsupervised hierarchical clustering analysis also revealed the same cluster pattern according to cell type and there was no difference between ERC-B and ERC-E (Figure 4C).

Class comparison analysis was performed for the six cell types using BRB Array Tools (Ver 3.4.0), considering a p-value less than 0.001 as significant. Comparison of ERC-B and ERC-E showed 82 differentially expressed genes and a small fold change differences (data not shown). Due to small differences in gene expression between ERC culture under the two conditions, class comparisons and pathway analyses were subsequently conducted by comparing only ERC-B with the other groups. Almost three thousand genes (2974) were differentially expressed between ERC-B and fibroblasts, whereas 1030 genes were differentially expressed between BMSC and fibroblasts.

Between ERC-B and BMSC, 1923 genes were differentially expressed. Some of the most up-regulated genes in ERC-B when compared with BMSC included somatostatin 


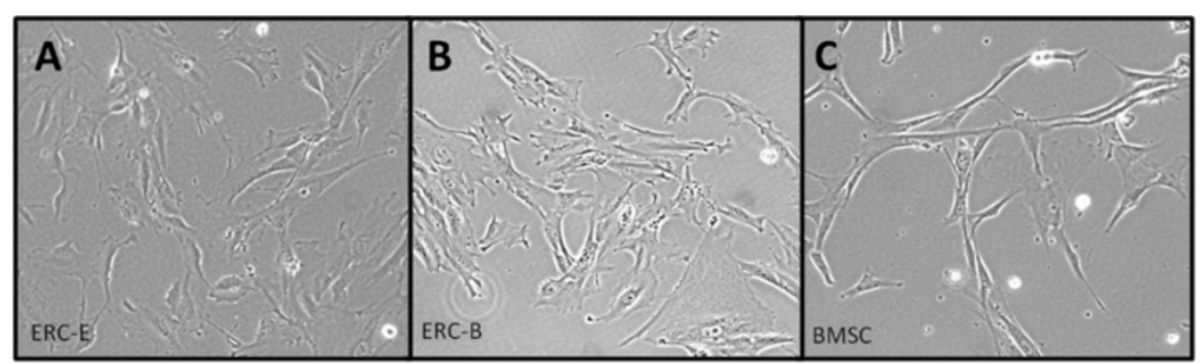

Figure 1 Comparison of ERC and BMSC morphology in various culture conditions. A: Early passage (P3) ERC cultured in ERC medium (10\% FBS in DMEM F-12). B: Early passage (P3) ERC from the same donor cultured in BMSC medium (20 \% FBS in aMEM). C: Early passage (P3) BMSC cultured in BMSC medium.

receptor 1 (SSTR1), TNFSF4, coagulation factor 3 (F3), and MMP3 (Table 4) while the most down-regulated genes in ERC-B included prostaglandin I2 synthase (PTGIS), prostaglandin-endoperoxide synthase 2 (PTGS2), vascular cell adhesion molecule 1 (VCAM1), and integrin alpha 10 (ITGA10) (Table 4).

Ingenuity Pathway Analysis (IPA) was performed to annotate the differentially expressed genes between ERC and BMSC. This analysis revealed that the up-regulated genes in ERC-B were involved in many of the top canonical pathways, including pro-inflammatory pathways such as IL-1 and IL-8 signaling and immune response pathways such as interferon signaling, CD27 signaling in lymphocytes, B cell receptor signaling, and NF- $\mathrm{KB}$ activation by viruses, IL17a signaling, CD40 signaling and antigen presentation (Figure 5). Pathways over represented among genes down-regulated in ERC-B were Hepatic fibrosis/hepatic stellate cell activation, TGF-B signaling, atherosclerosis signaling, mTor signaling, human embryonic stem cell pluripotency and hedgehog signaling and the cancer signaling pathways, ovarian cancer signaling, basal cell carcinoma and HER-2 signaling in breast cancer (Figure 6).

\section{Biologically relevant genes preferentially expressed in ERC vs BMSC}

Analysis of genes preferentially expressed in ERC vs BMSC based on biological significance was performed manually. Several genes of interest were identified. FoxL2 transcript, a transcription factor essential for

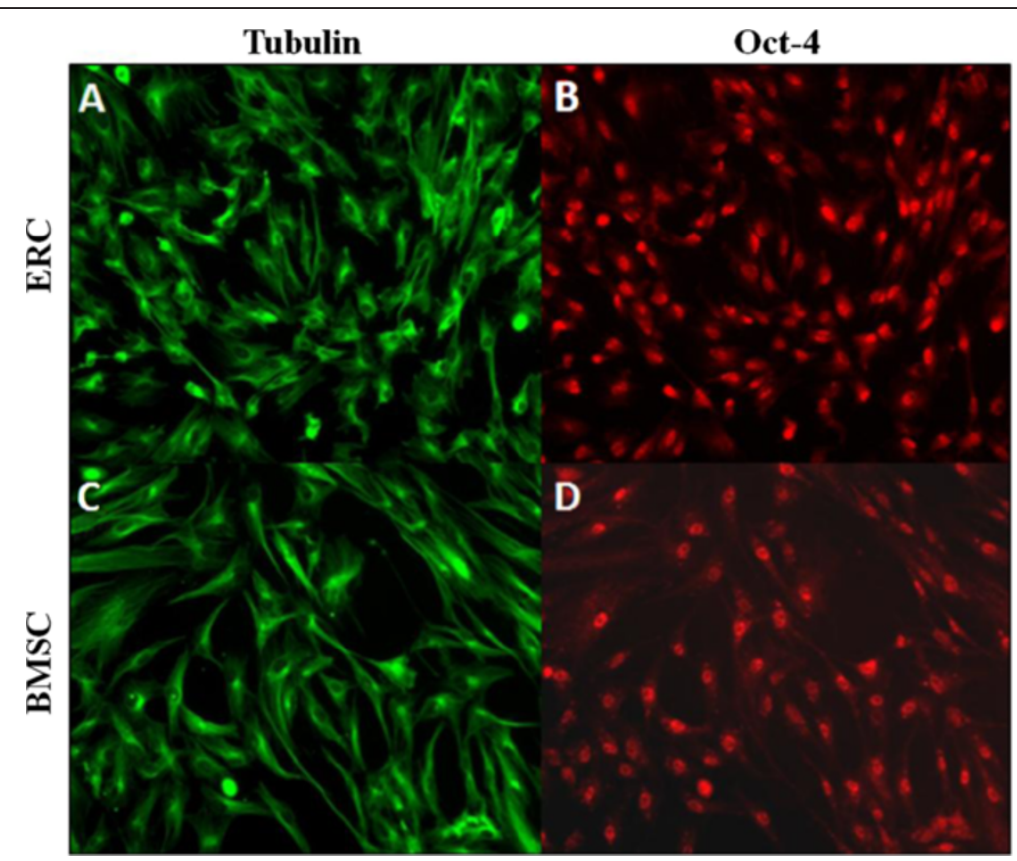

Figure 2 Immunofluorescence staining of ERC and BMSC. A-B: ERC were labeled for tubulin (A) and the embryonic stem cell marker Oct-4 (B), 10X magnification. C-D: Immunofluorescence staining of BMSC for tubulin (C) and Oct-4 (D), 10X magnification. 
Table 2 Mean pixel intensity values from cytokine array panels of BMSC and ERC-B supernatants

\begin{tabular}{|c|c|c|c|c|c|c|}
\hline Cell Type $^{*}$ & CXCL1 & sICAM-1 & IL-8 & CCL2 & MIF & Serpin E1 \\
\hline BMSC 1 & 64.1 & 0.5 & 105.8 & 154.0 & 427.4 & 359.6 \\
\hline BMSC 2 & 35.2 & 0.0 & 89.4 & 1.3 & 175.2 & 222.4 \\
\hline BMSC 3 & 20.7 & 0.0 & 23.2 & 1.3 & 174.5 & 169.1 \\
\hline Mean $\pm 1 S D$ & $40.0 \pm 22.1$ & $0.2 \pm 0.3$ & $72.8 \pm 43.7$ & $52.2 \pm 88.2$ & $259.0 \pm 145.8$ & $250.4 \pm 98.3$ \\
\hline ERC 1 & 43.2 & 40.8 & 903.7 & 16.9 & 434.7 & 333.5 \\
\hline ERC 2 & 2.0 & 1.7 & 152.3 & 0.0 & 24.0 & 239.8 \\
\hline$\overline{\text { ERC } 3}$ & 24.3 & 46.7 & 236.2 & 0.4 & 109.1 & 161.9 \\
\hline Mean $\pm 1 S D$ & $23.2 \pm 20.6$ & $29.7 \pm 24.5$ & $430.7 \pm 411.8$ & $5.8 \pm 9.6$ & $189.3 \pm 216.8$ & $245.1 \pm 85.9$ \\
\hline
\end{tabular}

*Three BMSC and 3 ERC different donors were analyzed.

ovary development [20] was expressed 80.5-fold higher in ERC compared to BMSC (Table 5). Mindin (SPON2) transcript, an innate immunity receptor involved in bacterial recognition[21] was expressed 53.5-fold higher as compared to BMSC. The stem cell potency marker, aldehyde dehydrogenase [22] was expressed at transcript level 39.5-fold higher. Immune modulatory proteins pregnancy associated glycoprotein 1 [23] and GM-CSF [24] were expressed 30.5- and 5.0-fold higher. Angiogenesis associated proteins Angiopoietin-1 [25] and PDGF [26] were expressed 13.8- and 26.9-fold higher. The matrix metalloprotease 3[27] transcript was 29.2-fold higher expressed as compared to BMSC. Interestingly, a comparison of MSC to ERC by Meng et al. revealed that ERC possessing substantially higher protein production of Angiopoietin, PDGF, GM-CSF and MMP3 as compared to MSC [14].

\section{Quantitative RT-PCR results}

Quantitative RT-PCR analysis was performed to confirm the expression of differentially expressed genes between ERC-B and BMSC. The raw data was calculated based on an 18sRNA endogenous control, and $\log 2-$ transformed fold change against the BMSC was calculated based on the $\Delta \Delta \mathrm{Ct}$ values. Fold changes between ERC-B and ERC-E for most genes were less than 2-fold with the exception of IL-8 and PTGS2, which had 2.5fold and 1.3-fold differences, respectively confirming that there was little difference in ERC grown in the different media (Figure 7). In addition, the expression of TNFSF4, MMP3, IL-8, and ICAM-1 was several fold greater in ERC with respect to BMSC, while the expression VCAM-1, PTGS2, ITGA-10 was several fold lower in ERC than in BMSC. These data were in good accordance with our microarray finding.

\section{miRNA microarray analysis}

A miRNA profiling was performed on ERC-B, BMSC, fibroblasts, ESC, and HSC. PCA analysis showed three distinct clusters. The BMSC, ERC, and fibroblasts were again closely grouped together, and they were also clustered close to the ESC samples (Figure 8-A). HSC were in a third distinct group of their own. The hierarchical clustering analysis of the samples also showed that BMSC, ERC, and fibroblasts formed a mixed cluster, instead HSC and ESC samples formed two separate clusters (Figure 8-B).

\section{Discussion}

The increased interest in MSC for therapeutic applications in recent years has led to many new discoveries of regenerative cells from different origins. In addition to ERC and

Table 3 Detected levels of cytokines in BMSC and ERC-B supernatants (pg/ml)

\begin{tabular}{|c|c|c|c|c|c|c|}
\hline Cell Type & HGF & VEGF & IL-6 & CXCL12 & TGFB1 & TGFB2 \\
\hline BMSC1 & 3344 & 31425 & 84151 & 9605 & 33659 & 12466 \\
\hline BMSC2 & 538 & 13345 & 10596 & 21072 & 38135 & 6766 \\
\hline BMSC3 & 617 & 10013 & 20350 & 8161 & 31963 & 3873 \\
\hline Mean \pm 1SD & $1500 \pm 1598$ & $18261 \pm 11521$ & $38366 \pm 39950$ & $12946 \pm 7074$ & $34586 \pm 3189$ & $7701 \pm 4372$ \\
\hline ERC1 & 224 & 4 & 449 & 7093 & 20282 & 2933 \\
\hline ERC2 & 44 & 13 & 108 & 540 & 19294 & 2934 \\
\hline ERC3 & 216 & 0.0 & 1394 & 12249 & 25577 & 2747 \\
\hline Mean \pm 1SD & $161 \pm 102$ & $5.7 \pm 6.6$ & $650 \pm 666$ & $6627 \pm 5868$ & $21718 \pm 3379$ & $2871 \pm 108$ \\
\hline BMSC CM & 15.2 & 6.5 & 0.1 & 8.5 & 12014.6 & 1546.1 \\
\hline
\end{tabular}

*Three BMSC and 3 ERC donors were analyzed.

$B M S C C M=$ Bone marrow stromal cell culture media. 


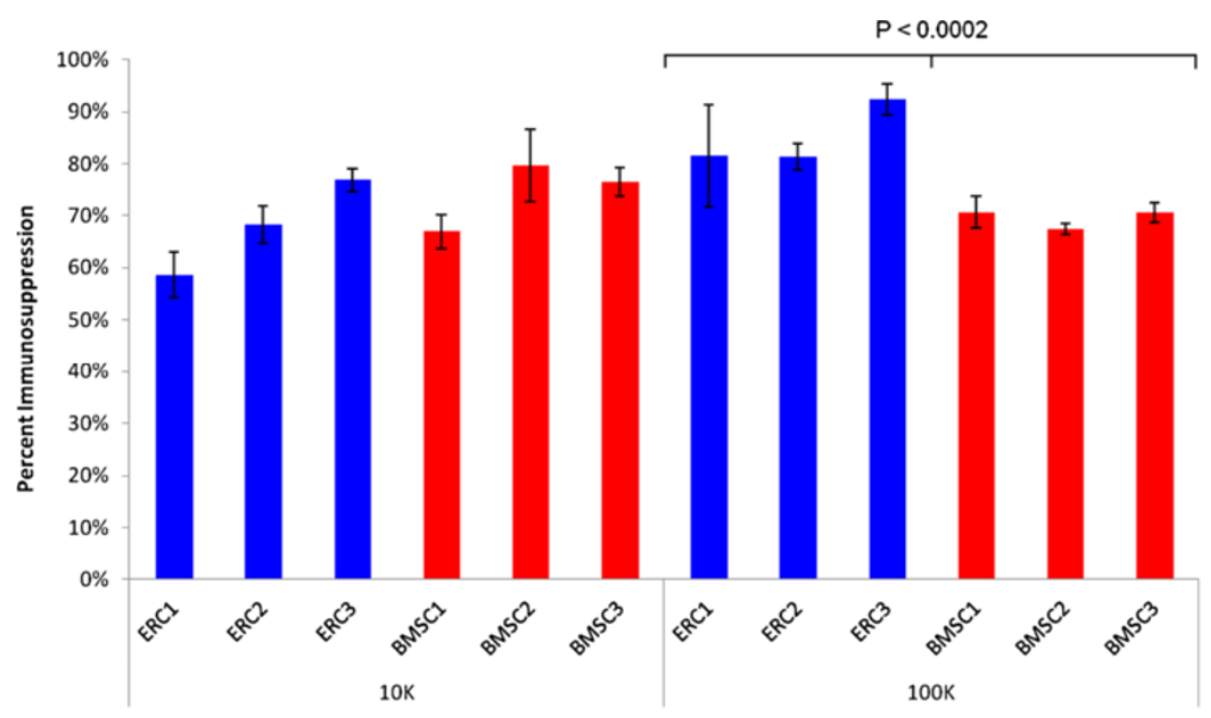

Figure 3 Immunosuppression of T cell responses in mixed lymphocyte reactions (MLRs) by ERC-B and BMSC. The bars indicate responder T cell proliferation when incubated with irradiated T cell stimulator cells and ERC-B or BMSC. Two doses of ERC-B and BMSC were tested: 10,000 and 100,000 cells. The measures were performed in triplicate and converted to percent immunosuppression by normalizing to the proliferation of T cells without BMSC co-incubation.

BMSC, other MSC have been used clinically or considered for clinical use and the group includes those derived from adipose tissue and umbilical cord blood. There have been some comparisons of the different types of stromal cells but this is the first comparison between ERC and BMSC both of which are being tested in clinical trials.

BMSC have been compared with other types of stromal cells including adipose tissue, lung tissue and umbilical cord blood derived MSC [28-32]. These studies have found that stromal cells produced from these various cell and tissue types have a similar phenotype [28-32]. All express CD44, CD73, CD90 and CD105, but do not express hematopoietic cell markers. They all demonstrate some degree of osteoblastic, chondrogenic and adipogenic differentiation ability, but there were some differences in differentiation ability among them [30,31], particularly when expression of differentiation markers were compared $[29,32,33]$. In addition the proliferation of stromal cells derived from diverse sources sometimes differ $[28,31]$. Stromal cells derived from different tissues can modulate immune function, but the degree of immune modulation can vary. For example, BMSC and adipose tissue derived-MSC differ in their ability to modulated the production of immunoglobulin by mitogen-stimulated B cells [30] and the proliferation of allogeneic $\mathrm{T}$ cells [34]. Some studies have also found differences in the expression of genes encoding cytokines and growth factors among rat adipose tissue MSC, rat cartilage MSC and rat BMSC [33]. None of these studies have compared global gene or miRNA expression among different types of stromal cells. The results of our study were similar to previous reports in that BMSC and ERC had similar morphology and proliferation, but we found some differences in gene expression in addition to the differences in cytokine and growth factor production.

We noted morphological differences between ERC and BMSC, but both cells resemble fibroblasts and morphology differences have also been noted between other types of MSC [34]. The PDTs of ERC and BMSC were similar, with BMSC having a slightly shorter PDT. Our PDT findings for ERC differed from those found from earlier literature, which was reported to be around 19 hours. This difference may be due to slight variations to the culture media formula and culture conditions. Immunofluorescence staining showed that both ERC and BMSC were positive for the pluripotency marker Oct-4, which is consistent with findings from earlier studies [14]. Comparison of miRNA expression signatures also found that ERC were very similar to BMSC.

Gene expression analysis revealed considerable similarities between ERC and BMSC, but there were also distinct differences between these two types of cells. Many immunity and inflammation related pathways were overrepresented among genes differentially expressed between ERC and BMSC suggesting that they may have different immune modulatory and antiinflammatory properties. This is supported by qRT-PCR analysis which showed that the expression of TNFSF4, MMP3, IL-8 and ICAM-1 were greater in ERC, and that of VCAM-1, PTGS2 and ITGA10 were greater in BMSC. Comparison of the levels of cytokines and growth factors in ERC and BMSC supernatants also 


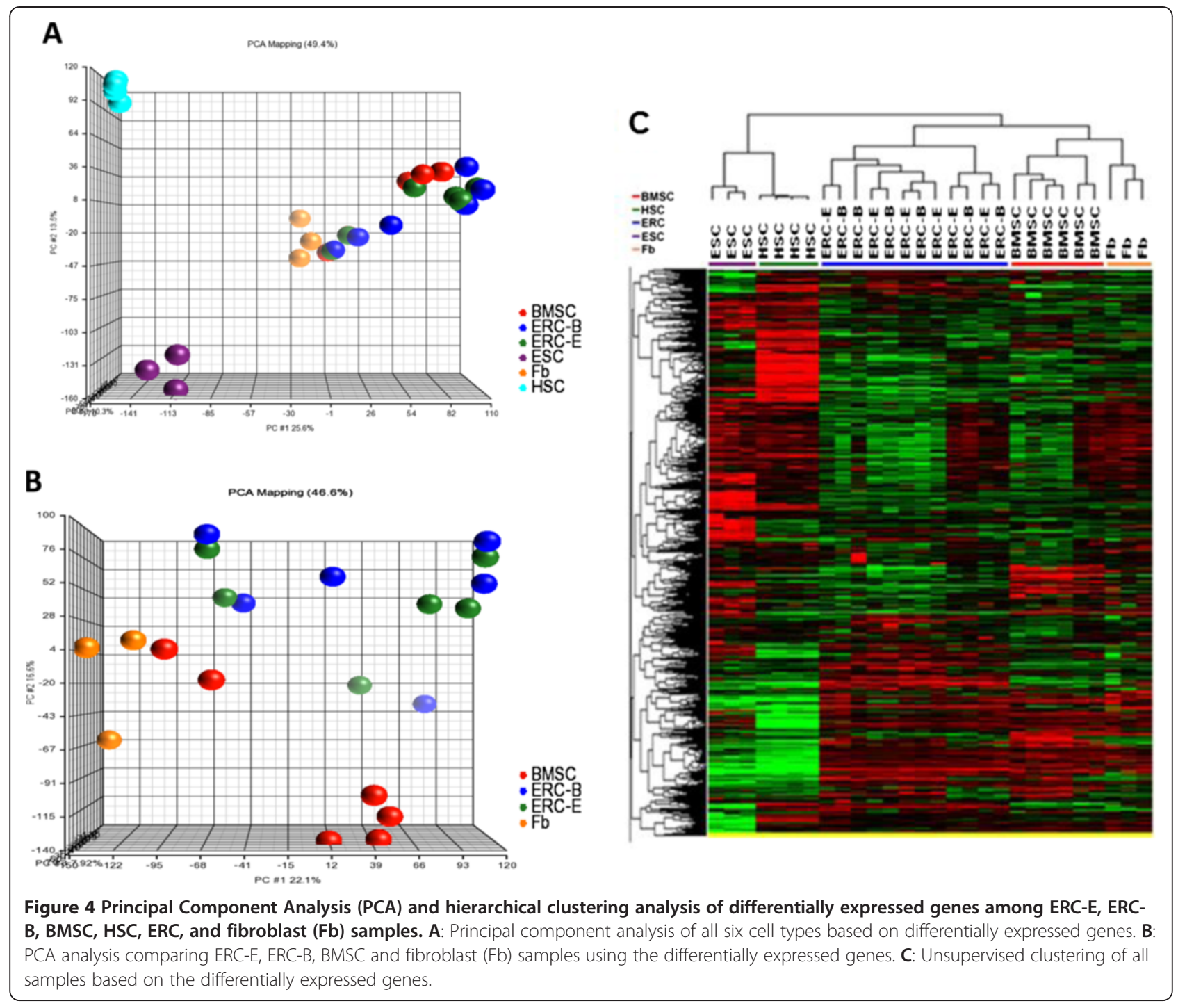

found difference among ERC and BMSC. The levels of IL-8 and ICAM-1 were greater in ERC supernatants and the levels of HGF, VEGF, TGFB2 and IL-6 were greater in BMSC supernatants. We found slight differences in the inhibition of MLRs between ERC and BMSC; the ERC being slightly more inhibitory. Interesting, adipose derived MSC have been found to be more immunomodulatory than BMSC[30,34]. In addition, the expression of two factors important in angiogenesis differed among these two types of stromal cells; MMP-3 was greater in ERC at the transcript level and VEGF was greater in BMSC supernatants at the protein level. This suggests the ability of ERC and BMSC to support angiogenesis may also differ. Specific analysis of biologically relevant genes that were overexpressed in ERC revealed substantially higher expression of genes associated with angiogenesis, including PDGF, and Angiopoietin-1. This is of interest since a previous publication by Meng et al., reported higher protein expression of MMP-3, angiopoietin, and PDGF [14].

Global gene and miRNA expression analysis found that fibroblasts were similar to ERC and BMSC. This is consistent with the fact that, like ERC and BMSC, fibroblasts express $\mathrm{CD} 73$ and $\mathrm{CD} 105$ and lack hematopoietic markers CD14, CD34 and CD45 and they demonstrate osteogenic, chondrogenic and adipogenic differentiation $[35,36]$. They also have immunosuppressive properties. They can inhibit mitogen and allogeneic stimulated $\mathrm{T}$ cell proliferation and interferon$\gamma$ production [35,37].

The results of this study show that although ERC and BMSC are currently being tested in clinical trials for similar indications, they may not have identical clinical effects. While our studies found a number of differences in gene expression, protein production and in vitro function which suggest that these two cell types may differ in 
Table 4 Genes differentially expressed between ERC and BMSC

\begin{tabular}{|c|c|c|c|c|c|}
\hline & $\begin{array}{l}\text { Genes } \\
\text { up-regulated } \\
\text { in } \mathrm{ERC}^{*}\end{array}$ & Fold-increase & & $\begin{array}{c}\text { Genes } \\
\text { down-regulated } \\
\text { in ERC* }\end{array}$ & Fold-decrease \\
\hline SSTR1 & $\begin{array}{l}\text { Somatostatin } \\
\text { receptor } 1\end{array}$ & 421.4 & CYP1B1 & $\begin{array}{l}\text { Cytochrome P450, } \\
\text { family } 1 \text {, subfamily B }\end{array}$ & 423.4 \\
\hline C3orf72 & $\begin{array}{l}\text { Chromosome } 3 \text { open } \\
\text { eading frame } 72\end{array}$ & 299.2 & CYP1B1 & $\begin{array}{l}\text { Cytochrome P450, family } 1 \text {, } \\
\text { subfamily B, clone }\end{array}$ & 258.4 \\
\hline F3 & Coagulation factor III & 182.5 & $\mathrm{IRX} 3$ & Iroquois homeobox 3 & 199.2 \\
\hline TNFSF4 & $\begin{array}{l}\text { Tumor necrosis factor } \\
\text { superfamily, member } 4\end{array}$ & 93.7 & SLC14A1 & $\begin{array}{l}\text { Solute carrier family } 14 \\
\text { member } 1 \text {, transcript variant } 3\end{array}$ & 172.8 \\
\hline$\overline{F O X L 2}$ & Forkhead box L2 & 80.5 & PITX2 & Paired-like homeodomain 2 & 167.7 \\
\hline FAM105A & $\begin{array}{l}\text { Family w/sequence } \\
\text { similarity } 105, \text { member A }\end{array}$ & 80.0 & BAALC & $\begin{array}{c}\text { Brain \& acute leukemia, } \\
\text { cytoplasmic, transcript var. } 2\end{array}$ & 146.4 \\
\hline SYNPO2L & $\begin{array}{l}\text { Synaptopodin 2-like, } \\
\text { transcript variant } 1\end{array}$ & 78.4 & PTGIS & Prostaglandin 12 synthase & 85.3 \\
\hline SLCO2A1 & $\begin{array}{l}\text { Solute carrier organic anion } \\
\text { transporter family, member } 2 \mathrm{~A} 1\end{array}$ & 64.6 & $\mathrm{IRX5}$ & Iroquois homeobox 5 & 81.3 \\
\hline ANO4 & Anoctamin 4 & 58.5 & PRDM16 & PR domain containing 16, transcript var. 2 & 77.8 \\
\hline SPON2 & $\begin{array}{l}\text { Spondin 2, extracellular } \\
\text { matrix protein, transcript var. } 3\end{array}$ & 53.5 & DLX5 & Distal-less homeobox 5 & 72.4 \\
\hline CARD16 & $\begin{array}{c}\text { Caspase recruitment } \\
\text { domain family, member 16, } \\
\text { transcript var. } 2\end{array}$ & 50.3 & PTGS2 & $\begin{array}{l}\text { Prostaglandin-endoperoxide } \\
\text { synthase } 2 \text { (prostaglandin G/H } \\
\text { synthase and cyclooxygenase) }\end{array}$ & 71.7 \\
\hline$\overline{\text { VAT1L }}$ & $\begin{array}{l}\text { Vesicle amine transport } \\
\text { protein } 1 \text { homolog-like }\end{array}$ & 46.4 & COLEC12 & Collectin sub-family member 12 & 66.9 \\
\hline NBLA00301 & Nbla00301 non-coding RNA & 44.6 & KRTAP1-1 & Keratin associated protein 1-1 & 62.6 \\
\hline INMT & $\begin{array}{c}\text { Indolethylamine } \\
\text { N-methyltransferase, } \\
\text { transcript var.2 }\end{array}$ & 42.8 & TBX15 & T-box 15 & 62.4 \\
\hline $\mathrm{DlO} 2$ & $\begin{array}{l}\text { Deiodinase iodothyronine } \\
\text { type II, transcript variant } 5\end{array}$ & 41.7 & PDLIM3 & $\begin{array}{l}\text { PDZ and LIM domain 3, } \\
\text { transcript variant } 1\end{array}$ & 57.8 \\
\hline $\mathrm{ALDH} 1 \mathrm{~A} 1$ & $\begin{array}{l}\text { Aldehyde dehydrogenase } \\
1 \text { family, member } A 1\end{array}$ & 39.5 & COMP & $\begin{array}{l}\text { Cartilage oligomeric } \\
\text { matrix protein }\end{array}$ & 54.4 \\
\hline HTR2B & $\begin{array}{l}\text { 5-hydroxytryptamine } \\
\text { (serotonin) receptor } 2 \mathrm{~B}\end{array}$ & 38.3 & GAP43 & $\begin{array}{c}\text { Growth associated protein } 43, \\
\text { transcript var. } 2\end{array}$ & 53.0 \\
\hline CARD17 & $\begin{array}{c}\text { Caspase recruitment domain } \\
\text { family member } 17\end{array}$ & 35.9 & VCAM1 & $\begin{array}{l}\text { Vascular cell adhesion molecule } 1, \\
\text { transcript var.2 }\end{array}$ & 52.0 \\
\hline ARHGAP20 & $\begin{array}{l}\text { Rho GTPase activating } \\
\text { protein } 20\end{array}$ & 35.3 & ITGA10 & Integrin, alpha 10 & 50.2 \\
\hline ZBTB46 & $\begin{array}{l}\text { Zinc finger and BTB } \\
\text { domain containing } 46\end{array}$ & 34.3 & LRRC15 & $\begin{array}{c}\text { Leucine rich repeat containing } 15, \\
\text { transcript variant } 2\end{array}$ & 48.9 \\
\hline SYNPO2L & $\begin{array}{l}\text { Synaptopodin 2-like } \\
\text { transcript variant } 1\end{array}$ & 34.3 & SLC14A1 & $\begin{array}{c}\text { Solute carrier family } 14 \text { (urea transporter), } \\
\text { member } 1 \text {, transcript variant } 4\end{array}$ & 48.4 \\
\hline C13orf15 & $\begin{array}{l}\text { Chromosome } 13 \text { open } \\
\text { reading frame } 15\end{array}$ & 33.5 & FLG & Filaggrin & 48.2 \\
\hline HOXD11 & Homeobox D11 & 32.5 & DLX6 & Distal-less homeobox 6 & 47.3 \\
\hline$\overline{\text { OLR1 }}$ & $\begin{array}{l}\text { Oxidized low density } \\
\text { lipoprotein receptor } 1, \\
\text { transcript var. } 2\end{array}$ & 32.0 & CMKLR1 & $\begin{array}{c}\text { Chemokine-like receptor } 1 \text {, } \\
\text { transcript variant } 3\end{array}$ & 44.0 \\
\hline HOXD10 & Homeobox D10 & 30.7 & $\mathrm{CH} 25 \mathrm{H}$ & Cholesterol 25-hydroxylase $(\mathrm{CH} 25 \mathrm{H}), \mathrm{mRNA}$. & 43.4 \\
\hline PSG4 & $\begin{array}{l}\text { Pregnancy specific } \\
\text { beta-1-glycoprotein } 4\end{array}$ & 30.5 & PLAC9 & Placenta-specific 9 (PLAC9), mRNA. & 41.8 \\
\hline MMP3 & Matrix metallopeptidase 3 & 29.2 & PCOLCE2 & Procollagen C-endopeptidase enhancer 2 & 41.5 \\
\hline
\end{tabular}

$\mathrm{P}<0.0001$ for all genes.

*The genes most up- and down-regulated according to fold-change are listed. 


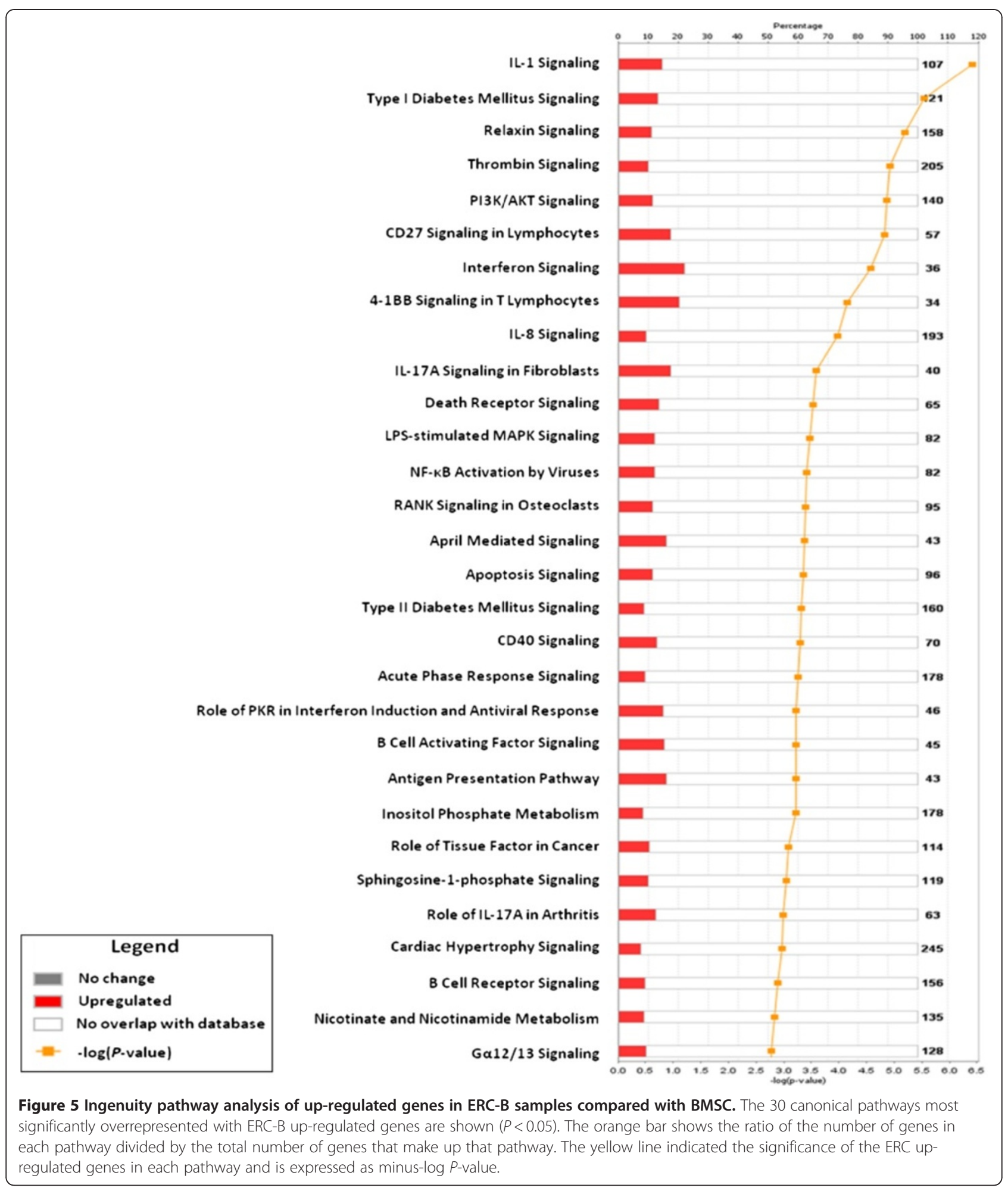

their immunomodulatory and anti-inflammatory effects, we cannot tell from these studies how they will perform in vivo or which cell type will have greater immunomodulatory or anti-inflammatory effects. We suspect that multiple properties of stromal cells are responsible for their in vivo effectiveness and ERC may be more effective for some of the clinical applications and BMSC for others. Studies in animal models or clinical trials will be required to more fully characterize the differences between ERC and BMSC. 


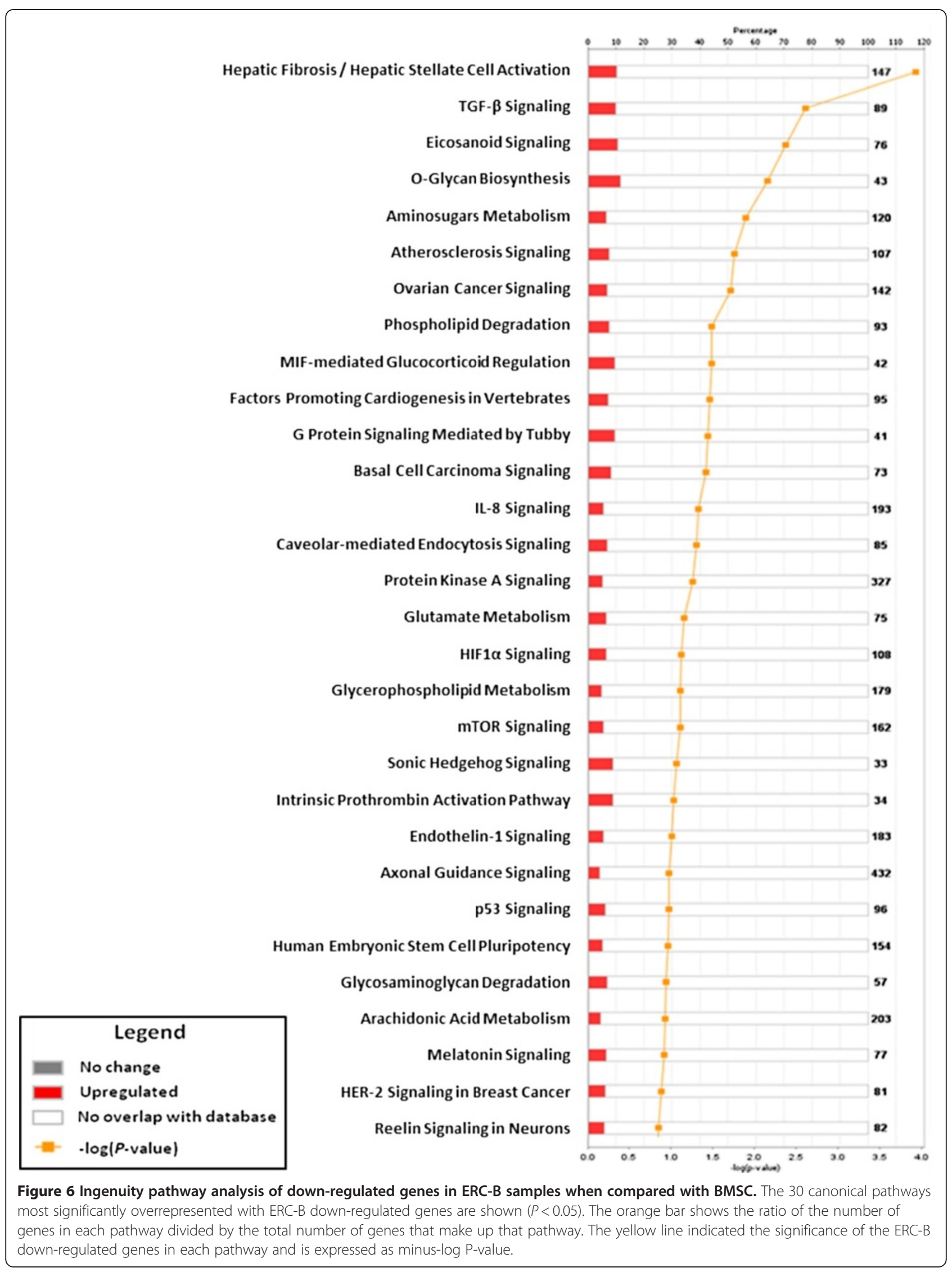


Table 5 Biologically-Relevant mRNA Expression Compared Between ERC and BMSC

\begin{tabular}{lccc}
\hline $\begin{array}{l}\text { Fold Higher } \\
\text { Expression in ERC }\end{array}$ & Gene & Property & Reference \\
\hline 80.5 -fold & FoxL2 & $\begin{array}{c}\text { Female-specific gonadal } \\
\text { differentiation transcription factor }\end{array}$ & [20] \\
\hline 53.5 -fold & Mindin (SPON2) & Bacterial recognition receptor & [21] \\
\hline 39.5 -fold & $\begin{array}{c}\text { Aldehyde } \\
\text { dehydrogenase }\end{array}$ & $\begin{array}{c}\text { Associated with stem cell } \\
\text { potency in hematopoietic stem cells, } \\
\text { angiogenic stem cells and cancer stem cells }\end{array}$ & $\begin{array}{c}\text { Anti-inflammatory product that } \\
\text { induces IL-10, protects fetus from } \\
\text { maternal immune system }\end{array}$ \\
\hline 30.5 -fold & $\begin{array}{c}\text { Pregnancy associated } \\
\text { glycoprotein 1 }\end{array}$ & $\begin{array}{c}\text { Tissue remodeling, angiogenesis } \\
\text { 29.2-fold }\end{array}$ & $\begin{array}{c}\text { Angiogenesis, } \\
\text { Matrix Metalloprotease 3 }\end{array}$ \\
\hline 26.9 -fold & PDGF & endothelial survival, vessel maturity & [27] \\
\hline 13.8 -fold & Angiopoietin & Stimulates angiogenesis & [25] \\
\hline 5.1 -fold & GM-CSF & hematopoiesis/inhibits autoimmuity &
\end{tabular}

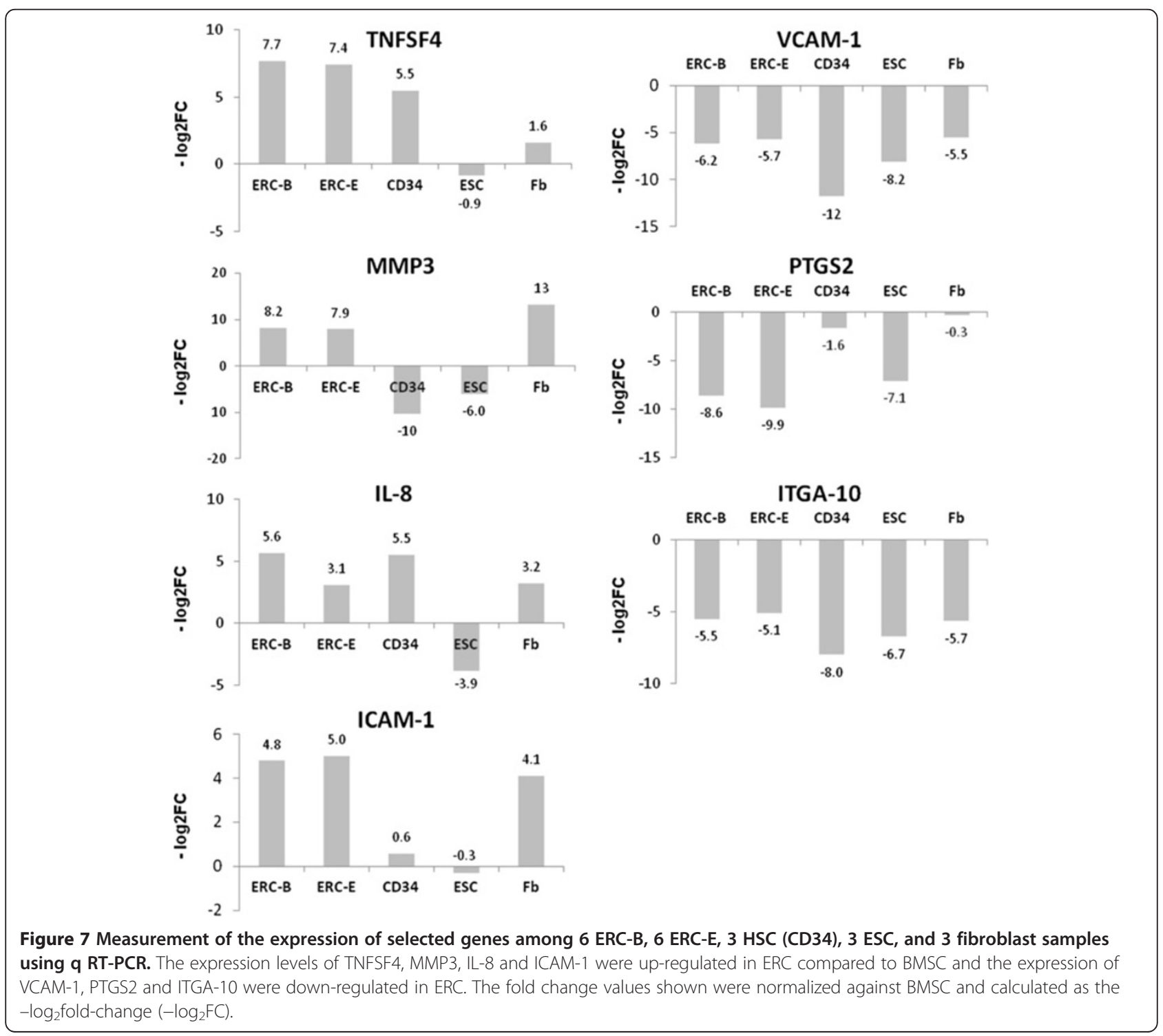




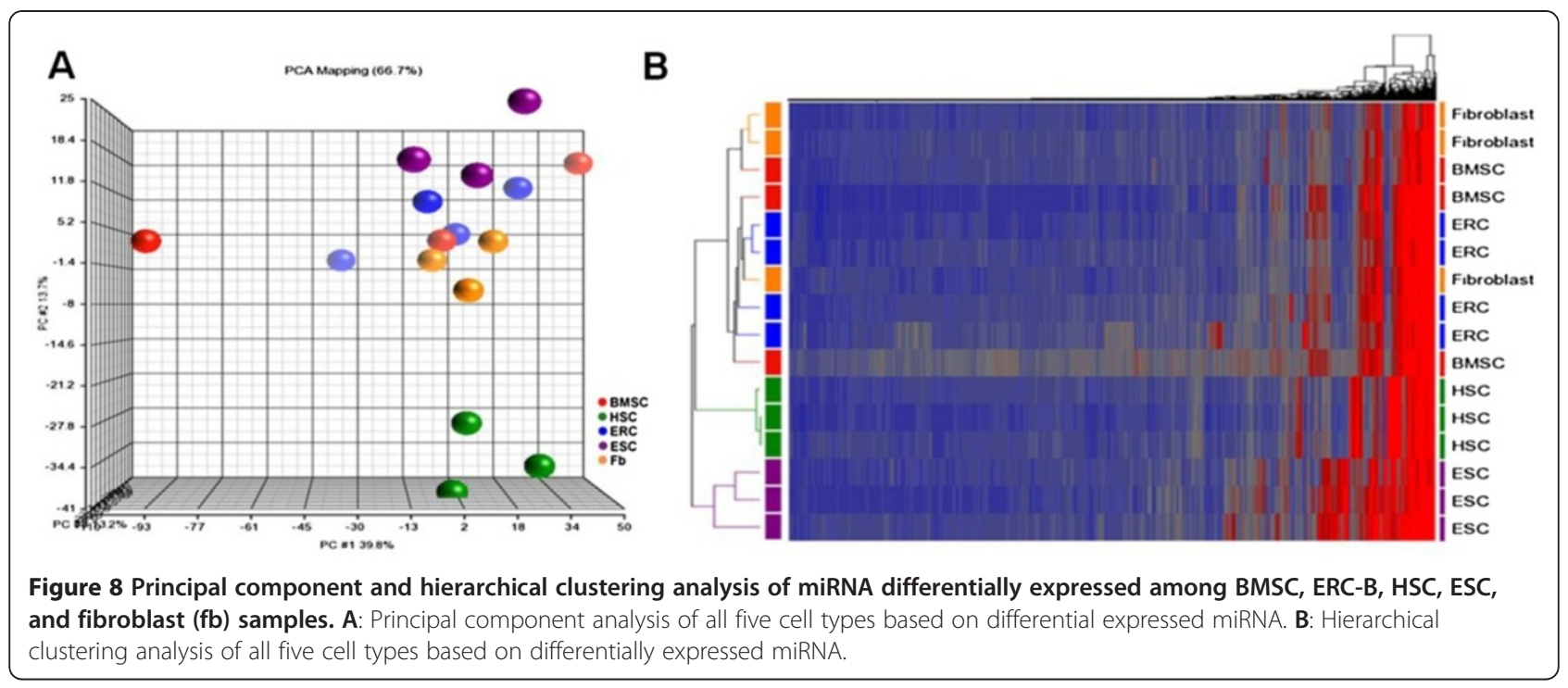

\section{Conclusions}

While the miRNA and gene expression signatures of ERC and BMSC are very similar, we found some differences in a number of immune and inflammatory pathways at the transcriptome and protein levels. The ability of ERC and BMSC to inhibit MLR also differed slightly. This suggests that the in vivo effects of these two types of MSC may also differ.

\section{Competing interests}

TEl and VB are employees and shareholders of Medistem (MEDS: Pinksheets) which produced the ERC.

\section{Authors' contributions}

HW helped design the study, performed experiments, analyzed data and wrote the manuscript. PJ assisted with the study design, preformed experiments, analyzed data analysis and helped write the manuscript. SC performed experiments and analyzed the data. MS helped design the study, analyzed the data and wrote the manuscript. JR provided the BMSC and preformed experiments and analyzed the data. DFS, TEl and VB conceived and helped design the studies. TEI and VB provided the ERC. DFS and TEI reviewed that data and helped write the manuscript. All of the authors read and approved the final manuscript.

\section{Acknowledgements}

We thank that the NIH Bone Marrow Stromal Cell Transplant Center for providing the BMSC used in this study. This research was supported by the Intramural Research Program of the NIH, Clinical Center.

\section{Author details}

'Department of Transfusion Medicine, Clinical Center, National Institutes of Health, Bethesda, MD, USA. ${ }^{2}$ MediStem Inc, San Diego, CA, USA. ${ }^{3}$ Department of Transfusion Medicine, Cell Processing Section, 10 Center Drive-MSC-1288, Building 10, Room 3C720, Bethesda, MD 20892-1288, USA.

Received: 31 July 2012 Accepted: 19 September 2012

Published: 5 October 2012

\section{References}

1. Friedenstein AJ, Chailakhjan RK, Lalykina KS: The development of fibroblast colonies in monolayer cultures of guinea-pig bone marrow and spleen cells. Cell Tissue Kinet 1970, 3:393-403.
2. Kolf CM, Cho E, Tuan RS: Mesenchymal stromal cells. biology of adult mesenchymal stem cells: regulation of niche, self-renewal and differentiation. Arthritis Res Ther 2007, 9:204.

3. Dominici M, Le BK, Mueller I, Slaper-Cortenbach I, Marini F, Krause D, Deans R, Keating A, Prockop D, Horwitz E: Minimal criteria for defining multipotent mesenchymal stromal cells. the international society for cellular therapy position statement. Cytotherapy 2006, 8:315-317.

4. Prockop DJ: Marrow stromal cells as stem cells for nonhematopoietic tissues. Science 1997, 276:71-74.

5. Pittenger MF, Mackay AM, Beck SC, Jaiswal RK, Douglas R, Mosca JD, Moorman MA, Simonetti DW, Craig S, Marshak DR: Multilineage potential of adult human mesenchymal stem cells. Science 1999, 284:143-147.

6. Kuznetsov SA, Mankani MH, Robey PG: In vivo formation of bone and haematopoietic territories by transplanted human bone marrow stromal cells generated in medium with and without osteogenic supplements. J Tissue Eng Regen Med 2011, doi:10.1002/term.515 [Epub ahead of print].

7. Zomorodian E, Baghaban EM: Mesenchymal stem cells as a potent cell source for bone regeneration. Stem Cells Int 2012, 2012:980353.

8. Le Blanc K, Frassoni F, Ball L, Locatelli F, Roelofs H, Lewis I, Lanino E, Sundberg B, Bernardo ME, Remberger M, Dini G, Egeler RM, Bacigalupo A, Fibbe W, Ringden O: Mesenchymal stem cells for treatment of steroidresistant, severe, acute graft-versus-host disease: a phase II study. Lancet 2008, 371:1579-1586.

9. Le Blanc K, Rasmusson I, Sundberg B, Gotherstrom C, Hassan M, Uzunel M, Ringden O: Treatment of severe acute graft-versus-host disease with third party haploidentical mesenchymal stem cells. Lancet 2004, 363:1439-1441.

10. Ringden O, Uzunel M, Rasmusson I, Remberger M, Sundberg B, Lonnies H, Marschall HU, Dlugosz A, Szakos A, Hassan Z, Omazic B, Aschan J, Barkholt L, Le BK: Mesenchymal stem cells for treatment of therapy-resistant graftversus-host disease. Transplantation 2006, 81:1390-1397.

11. Gilchrist ES, Plevris JN: Bone marrow-derived stem cells in liver repair: 10 years down the line. Liver Transpl 2010, 16:118-129.

12. Zhou Y, Wang S, Yu Z, Hoyt RF Jr, Sachdev V, Vincent P, Arai AE, Kwak M, Burkett SS, Horvath KA: Direct injection of autologous mesenchymal stromal cells improves myocardial function. Biochem Biophys Res Commun 2009, 390:902-907.

13. Ciccocioppo R, Bernardo ME, Sgarella A, Maccario R, Avanzini MA, Ubezio C, Minelli A, Alvisi C, Vanoli A, Calliada F, Dionigi P, Perotti C, Locatelli F, Corazza GR: Autologous bone marrow-derived mesenchymal stromal cells in the treatment of fistulising Crohn's disease. Gut 2011, 60:788-798.

14. Meng X, Ichim TE, Zhong J, Rogers A, Yin Z, Jackson J, Wang H, Ge W, Bogin V, Chan KW, Thebaud B, Riordan NH: Endometrial regenerative cells: a novel stem cell population. J Trans/ Med 2007, 5:57. 
15. Murphy MP, Wang H, Patel AN, Kambhampati S, Angle N, Chan K, Marleau AM, Pyszniak A, Carrier E, Ichim TE, Riordan NH: Allogeneic endometrial regenerative cells: an "Off the shelf solution" for critical limb ischemia? J Transl Med 2008, 6:45.

16. Han X, Meng X, Yin Z, Rogers A, Zhong J, Rillema P, Jackson JA, Ichim TE, Minev B, Carrier E, Patel AN, Murphy MP, Min WP, Riordan NH: Inhibition of intracranial glioma growth by endometrial regenerative cells. Cell Cycle 2009, 8:606-610.

17. Zhong Z, Patel AN, Ichim TE, Riordan NH, Wang H, Min WP, Woods EJ, Reid M, Mansilla E, Marin GH, Drago H, Murphy MP, Minev B: Feasibility investigation of allogeneic endometrial regenerative cells. J Trans/ Med 2009, 7:15.

18. Simon R, Lam A, Li MC, Ngan M, Menenzes S, Zhao Y: Analysis of gene expression data using BRB-ArrayTools. Cancer Inform 2007, 3:11-17.

19. Doorn J, Moll G, Le Blanc K, van Blitterswijk C, de Boer J: Therapeutic applications of mesenchymal stromal cells: paracrine effects and potential improvements. Tissue Eng Part B Rev 2012, 18:101-115.

20. Veitia RA: FOXL2 versus SOX9: a lifelong "battle of the sexes. Bioessays 2010, 32:375-380

21. He YW, Li H, Zhang J, Hsu CL, Lin E, Zhang N, Guo J, Forbush KA, Bevan MJ: The extracellular matrix protein mindin is a pattern-recognition molecule for microbial pathogens. Nat Immunol 2004, 5:88-97.

22. Balber AE: Concise review: aldehyde dehydrogenase bright stem and progenitor cell populations from normal tissues: characteristics, activities, and emerging uses in regenerative medicine. Stem Cells 2011, 29:570-575.

23. Snyder SK, Wessner DH, Wessells JL, Waterhouse RM, Wahl LM, Zimmermann W, Dveksler GS: Pregnancy-specific glycoproteins function as immunomodulators by inducing secretion of IL-10, IL- 6 and TGFbeta1 by human monocytes. Am J Reprod Immunol 2001, 45:205-216.

24. Fleetwood AJ, Cook AD, Hamilton JA: Functions of granulocytemacrophage colony-stimulating factor. Crit Rev Immunol 2005, 25:405-428.

25. Fiedler $U$, Augustin HG: Angiopoietins: a link between angiogenesis and inflammation. Trends Immunol 2006, 27:552-558.

26. Hellberg C, Ostman A, Heldin CH: PDGF and vessel maturation. Recent Results Cancer Res 2010, 180:103-114.

27. Zheng L, Amano K, lohara K, Ito M, Imabayashi K, Into T, Matsushita K, Nakamura $\mathrm{H}$, Nakashima M: Matrix metalloproteinase-3 accelerates wound healing following dental pulp injury. Am J Pathol 2009, 175:1905-1914.

28. Vishnubalaji $R$, Al-Nbaheen M, Kadalmani B, Aldahmash A, Ramesh $T$ : Comparative investigation of the differentiation capability of bonemarrow- and adipose-derived mesenchymal stem cells by qualitative and quantitative analysis. Cell Tissue Res 2012, 347:419-427.

29. Rebelatto CK, Aguiar AM, Moretao MP, Senegaglia AC, Hansen P, Barchiki F, Oliveira J, Martins J, Kuligovski C, Mansur F, Christofis A, Amaral VF, Brofman PS, Goldenberg S, Nakao LS, Correa A: Dissimilar differentiation of mesenchymal stem cells from bone marrow, umbilical cord blood, and adipose tissue. Exp Biol Med (Maywood) 2008, 233:901-913.

30. Bochev I, Elmadjian G, Kyurkchiev D, Tzvetanov L, Altankova I, Tivchev P, Kyurkchiev S: Mesenchymal stem cells from human bone marrow or adipose tissue differently modulate mitogen-stimulated B-cell immunoglobulin production in vitro. Cell Biol Int 2008, 32:384-393.

31. Kern S, Eichler H, Stoeve J, Kluter H, Bieback K: Comparative analysis of mesenchymal stem cells from bone marrow, umbilical cord blood, or adipose tissue. Stem Cells 2006, 24:1294-1301.

32. Nora CC, Camassola M, Bellagamba B, Ikuta N, Christoff AP, Meirelles LD, Ayres R, Margis R, Nardi NB: Molecular analysis of the differentiation potential of murine mesenchymal stem cells from tissues of endodermal or mesodermal origin. Stem Cells Dev 2012, 21:1761-1768.

33. Peng $L$, Jia Z, Yin X, Zhang X, Liu Y, Chen P, Ma K, Zhou C: Comparative analysis of mesenchymal stem cells from bone marrow, cartilage, and adipose tissue. Stem Cells Dev 2008, 17:761-773.

34. Keyser KA, Beagles KE, Kiem HP: Comparison of mesenchymal stem cells from different tissues to suppress T-cell activation. Cell Transplant 2007, 16:555-562.

35. Haniffa MA, Collin MP, Buckley CD, Dazzi F: Mesenchymal stem cells: the fibroblasts' new clothes? Haematologica 2009, 94:258-263.

36. Lysy PA, Smets F, Sibille C, Najimi M, Sokal EM: Human skin fibroblasts: From mesodermal to hepatocyte-like differentiation. Hepatology 2007, 46:1574-1585.
37. Haniffa MA, Wang XN, Holtick U, Rae M, Isaacs JD, Dickinson AM, Hilkens CM, Collin MP: Adult human fibroblasts are potent immunoregulatory cells and functionally equivalent to mesenchymal stem cells. J Immunol 2007, 179:1595-1604.

doi:10.1186/1479-5876-10-207

Cite this article as: Wang et al.: Comparison of endometrial regenerative cells and bone marrow stromal cells. Journal of Translational Medicine 2012 10:207.

\section{Submit your next manuscript to BioMed Central and take full advantage of:}

- Convenient online submission

- Thorough peer review

- No space constraints or color figure charges

- Immediate publication on acceptance

- Inclusion in PubMed, CAS, Scopus and Google Scholar

- Research which is freely available for redistribution 